\title{
PENGEMBANGAN E-MODUL FISIKA BERBASIS PENDEKATAN SAINTIFIK PADA MATERI TEORI KINETIK GAS
}

\author{
Irna Tri Putri ${ }^{1}$, Tugiyo Aminoto ${ }^{2}$, Febri Berthalita Pujaningsih ${ }^{3}$ \\ ${ }^{1,2,3}$ Program Studi Pendidikan Fisika FKIP Universitas Jambi, Jambi, Indonesia \\ Corresponding author email: irnatri96@gmail.com
}

\section{Info Artikel}

Diterima:

30 September 2019

Disetujui:

19 Mei 2020

Dipublikasikan:

30 Juni 2020

\begin{abstract}
Abstrak:
Penelitian ini dilatarbelakangi oleh kesulitan yang dialami siswa dalam memahami materi teori kinetik gas dan keterbatasan bahan ajar multimedia yang dimiliki guru. Tujuan penelitian ini adalah mengembangkan $e$-modul fisika berbasis berbasis Pendekatan Saintifik menggunakan 3D Pageflipp Professional pada materi teori kinetik gas dan untuk mengetahui persepsi siswa terhadap $e$-modul yang dikembangkan. Jenis Penelitian yaitu penelitian dan pengembangan dengan menggunakan model pengembangan ADDIE (Analyse, Design, Development, Implementation and Evaluation). Penelitian ini hanya sampai tahap Development. E-modul yang dihasilkan berfungsi sebagai sumber belajar mandiri siswa dan bahan ajar bantu yang dapat digunakan siswa di kelas dalam proses pembelajaran berbasis Pendekatan Saintifik. Hasil penelitian ini adalah $e$-modul yang dikembangkan melalui proses validasi oleh tim ahli dan dinyatakan layak untuk diuji cobakan kepada siswa. Dari hasil uji coba data persepsi siswa diperoleh disimpulkan $e$-modul ini baik untuk digunakan dalam proses pembelajaran.
\end{abstract}

Kata kunci: $E$-modul, 3D pageflip, teori kinetik gas

\begin{abstract}
:
This research is motivated by the difficulties experienced by students in understanding gas kinetic theory material and the limitations of multimedia teaching materials possessed by teachers. The purpose of this study is to develop a physics-based e-module based on the Scientific Approach using 3D Professional Pageflipp on the gas kinetic theory material and to determine students' perceptions of the e-modules developed. This type of research is research and development using the ADDIE development model (Analyze, Design, Development, Implementation and Evaluation). This research only reached the Development stage. The resulting e-module serves as a source of student independent learning and teaching materials that can be used by students in the classroom in the learning process based on the Scientific Approach. The results of this study are e-module that were developed through a validation process by a team of experts and were declared eligible to be tested on students. From the results of testing the students' perception data it was concluded that this e-module is good for use in the learning process.
\end{abstract}

Keywords: E-module, 3D professional, theory kinetic of gas 


\section{Pendahuluan}

Materi teori kinetik gas merupakan materi yang bersifat abstrak dan mikroskopis, karena cakupan kajiannya berkaitan dengan benda-benda yang tidak tampak oleh mata, oleh karenanya pembelajaran teori kinetik gas di SMA hendaknya didukung dengan media atau multimedia yang dapat membantu pemahaman siswa. Kesulitan yang dialami siswa dalam memahami konsep teori kinetik gas tidak hanya disebabkan faktor materi yang abstrak dan mikroskopis saja, akan tetapi ketidak tersediaan sarana yang memadai untuk mengeksplorasi konsep teori kinetik gas dan segala jenis hukum-hukum yang berlaku juga turut mempengaruhi (Yoto \& Wiyono, 2016) Pembelajaran yang dilakukan oleh guru saat ini masih berorientasi pada teacher centered, sehingga siswa cenderung pasif dalam pembelajaran yang pada akhirnya akan menimbulkan kebosanan dalam belajar. Oleh karena itu guru dituntut untuk berinovasi agar dapat membuat pembelajaran menarik dan peserta didik terlibat aktif di dalamnya. Untuk efektivitas dan efisiensi pembelajaran di kelas guru sudah seharusnya memanfaatkan aplikasi teknologi dalam pembelajaran, sehingga proses pembelajaran dikelas tidak membosankan dan siswa termotivasi untuk belajar.

Berdasarkan hasil penyebaran angket studi pendahuluan dan angket kebutuhan kepada siswa/i kelas XII MIPA 5 serta hasil angket wawancara terhadap guru fisika di SMA Negeri 1 Muaro Jambi, maka diketahui permasalahan inti yang terdapat di SMA Negeri 1 Muaro Jambi dalam proses pembelajaran fisika yaitu materi pelajaran tidak tersampaikan secara maksimal karena keterbatan bahan ajar multimedia yang dimiliki oleh guru dan kesulitan-kesulitan yang ditemukan siswa dalam mempelajari materi teori kinetik gas. Dari permasalahan-permasalahan tersebut, sehingga dibutuhkan suatu bahan ajar multimedia yang efektif dan mudah digunakan agar materi teori kinetik gas dapat dipelajari siswa secara maksimal, seperti bahan ajar multimedia yang mampu mengilustrasikan sifat dan keadaan partikel gas berukuran mikroskopis sehingga siswa dapat mentransformasikannya kedalam rumus. Dengan demikian, perlu dilakukan suatu pengembangan untuk menghasilkan produk bahan ajar multimedia materi teori kinetik gas. Selain itu, SMA Negeri 1 Muaro Jambi telah memiliki fasilitas laboratorium komputer, infokus dan siswa juga telah memiliki laptop, sehingga akan mendukung jika dilakukan pengembangan bahan ajar multimedia materi teori kinetik gas karena dapat diterapkan di dalam proses pembelajaran (sumber daya teknologi tersedia).

Untuk mengatasi permasalahan ini, maka perlu dilakukan inovasi pembelajaran yang dapat digunakan oleh siswa dalam belajar mandiri. Salah satunya adalah dengan mengembangkan bahan ajar yang dapat memotivasi siswa agar lebih aktif dan kreatif dengan software tertentu berupa e-modul (modul elektronik). Penggunaan bahan ajar berupa e-modul dengan konsep multimedia dalam format elektronik digunakan sebagai pengganti buku atau modul cetakan (hardcopy) tanpa mengurangi fungsinya sebagai sumber informasi. Dengan penggunaan bahan ajar berupa e-modul tersebut diharapkan dapat memberikan pembaharuan dalam pembelajaran.(Anggraini et al., 2017)

Salah satu bahan ajar multimedia yang dapat dikembangkan/disusun menggunakan $3 D$ Pageflip Professional adalah $e$-modul (modul elektronik). Menurut (Depdiknas, 2008). modul merupakan bahan ajar cetak yang dirancang untuk dapat dipelajari secara mandiri oleh peserta pembelajaran. Modul elektronik adalah modul yang ditransformasikan penyajiannya ke dalam bentuk elektronik (Ghaliyah et al., 2015). Sejalan dengan ini, menurut (Priatna et al., 2017) $e$-modul merupakan seperangkat media pengajaran digital dan non cetak yang disusun secara sistematis dan digunakan untuk keperluan belajar mandiri, sehingga dapat menuntut siswa untuk belajar memecahkan masalah dengan caranya sendiri. Pada umumnya modul tersedia dalam bentuk cetak, namun modul cetak memiliki beberapa kelemahan, yaitu dari segi tampilan terbatas karena hanya berupa teks dan gambar. Sedangkan $e$-modul yang disajikan secara elektronik, sehingga konten-konten seperti seperti video, animasi, simulasi dan sebagainya dapat ditambahkan ke dalam $e$-modul yang tidak dapat dilakukan pada modul cetak. Hal ini menjadikan $e$-modul jauh lebih unggul daripada modul cetak. $E$ modul yang akan dihasilkan ditujukan kepada siswa, dirancang sedemikian rupa dan sistematis yang dapat digunakan siswa untuk belajar mandiri dan dapat digunakan dalam proses pembelajaran yang berbasis pendekatan saintifik di kelas sebagai bahan ajar bantu. (Kemendikbud, 2014) memberi konsepsi bahwa pendekatan saintifik dalam pembelajaran terdiri atas lima pengalaman belajar pokok, yaitu: mengamati, menanya, mengumpulkan informasi, mengasosiasi dan mengkomunikasikan.

3D Pageflip Professional merupakan suatu software yang digunakan untuk membuat majalah 3D, Flash 3D, e-katalog, e-brosur e-paper dan lain-lain. Software ini dapat menambahkan video, 
gambar, audio, hyperlink, dan objek multimedia, sehingga bahan ajar menjadi lebih menarik. Disamping itu, bahan ajar akan terasa semakin menarik karena software ini mampu menghasilkan bahan ajar dengan efek 3D dan interaktif. Bahan ajar multimedia menggunakan 3D Pageflip Professional juga mudah digunakan oleh siapa saja.

Modul Elektronik perlu dikembangkan dengan pendekatan, metode ataupun model agar lebih terarah dan terstruktur karena adanya langkah-langkah dalam pembelajaran. Salah satu pendekatan yang diterapkan dalam Kurikulum 2013 adalah pendekatan saintifik. Pembelajaran dengan pendekatan saintifik adalah proses pembelajaran yang dirancang sedemikian rupa agar peserta didik secara aktif mengkonstruksi konsep, hukum atau prinsip melalui tahapantahapan pembelajaran yang melibatkan keterampilan proses seperti mengamati, mengklasifikasi, mengukur, meramalkan, menjelaskan, dan menyimpulkan. Karakteristik pembelajaran dengan pendekatan scientific menurut Daryanto (2014) adalah sebagai berikut:

a) Pembelajaran berpusat pada siswa.

b) Melibatkan keterampilan proses sains dalam mengkonstruksi konsep, hukum atau prinsip.

c) Melibatkan proses-proses kognitif yang potensial dalam meransang perkembangan intelek, khususnya keterampilan berfikir tingkat tinggi siswa.

d) Dapat mengembang karakter siswa.

Pengembangan modul elektronik juga pernah dilakukan oleh Sukiminiandari (2015) dalam penelitiannya memberikan saran yakni diharapkan pada penelitian selanjutnya peneliti dapat mengembangkan sebuah modul dengan inovasi terbaru yang berupa media pembelajaran yakni modul elektronik sehingga siswa lebih termotivasi dalam pembelajaran fisika dan membuat modul dengan menggunakan materi pembelajaran fisika lainnya. Selain itu Wahyuni (2013) juga memberikan saran pada peneliti selanjutnya untuk menambahkan animasi pada setiap kegiatan pembelajaran agar siswa lebih termotivasi lagi dalam belajar. Penelitian ini bertujuan untuk mengembangkan modul elektronik dengan pendekatan saintifik sebagai penunjang pembelajaran fisika pokok bahasan Materi Teori Kinetik Gas dan untuk mengetahui persepsi siswa terhadap modul leektronik tersebut.

\section{Metode Penelitian}

Metode penelitian yang peneliti gunakan adalah dengan model yaitu Analisis (Analyzing), Desain (Design), Pengembangan (Development), Implementasi (Implementation), dan Evaluasi (Evaluate) atau lebih sering disingkat dengan model ADDIE. Model ini memiliki beberapa tahapan yang sesuai dengan namanya yaitu (1) analisis, (2) Desain, (3) pengembangan, (4) Implementasi dan diakhiri dengan tahap (5) evaluasi, namun model ADDIE memiliki fokus atau penekanan pada iterasi dan refleksi. Sehingga perbaikan secara terus menerus dapat dilakukan yang berfokus dari umpan balik (Harjanta \& Herlambang, 2018)ADDIE merupakan singkatan dari analysis (analisis), design (desain), development (pengembangan), implementation (implementasi), dan evaluate (evaluasi). Model ADDIE dikenal dengan model melingkar. Model penelitian ADDIE merupakan sebuah akronim dari Analysis (menganalisis), Design (merancang), Development (mengembangkan), Implementation (mengimplementasikan), dan Evaluation (mengevaluasi) yang merupakan prosedur dari model penelitian ADDIE. ADDIE adalah konsep pengembangan produk (Branch, 2010).

Data yang diperoleh dari hasil pengembangan $e$-modul ini digunakan sebagai dasar dalam menetapkan kelayakan $e$-modul yang dihasilkan. Data yang dihasilkan dalam penelitian ini berupa data kualitatif dan data kuantitatif. Jenis data kualitatif adalah data yang dijelaskan dalam bentuk katakata, yang tidak dapat dianalisis dalam bentuk bilangan atau angka. Adapun data kualitatif dalam penelitian ini diperoleh dari angket validasi oleh tim ahli dan angket persepsi oleh siswa berupa masukan, tanggapan, kritik dan saran dalam perbaikan $e$-modul. Jenis data kuantitatif adalah jenis data yang dapat diukur atau dihitung dalam bentuk angka. Data kuantitatif diperoleh dari angket validasi oleh tim ahli dan angket persepsi siswa berupa skor penilaian terhadap $e$-modul. Skor penilaian menggunakan skala likert yang mempunyai range persentase.

Dalam penelitian pengembangan ini digunakan instrumen pengumpulan data yang dibutuhkan. Pengumpulan data pada penelitian ini menggunakan instrumen penelitian non tes dalam bentuk angket atau kuesioner. Kuesioner atau angket merupakan teknik pengumpulan data yang dilakukan dengan cara memberi seperangkat pertanyaan atau pertanyaan tertulis kepada respoden untuk dijawabnya (Sugiyono, 2018). Kuesioner (angket) yang digunakan berupa kuesioner tertutup, dimana responden 
hanya diminta untuk memilih jawaban yang telah disediakan di dalam angket. Angket studi pendahuluan diberikan kepada siswa. Angket studi pendahuluan ini berisi beberapa pertanyaanpertanyaan dasar sebagai alasan mengapa dikembangkannya $e$-modul oleh peneliti Angket Kebutuhan Siswa. Angket kebutuhan siswa berisi pertanyaan yang lebih mendetail mengenai keadaan siswa, keadaan sarana dan prasarana di sekolah apakah mendukung dikembangkannya $e$-modul dan lain-lain. Lembar wawancara dalam penelitian ini adalah lembar wawancara terstruktur dimana pewawancara sudah menyiapkan daftar pertanyaan sehingga proses wawancara akan terarah dengan baik. Instrumen angket validasi tim ahli ini digunakan untuk memperoleh data penilaian seperti pertimbangan, pendapat, komentar dan masukan dari tim ahli terhadap e-modul yang dikembangkan. Validasi Ahli bertujuan memperoleh pengakuan atau pengesahan $e$-modul apakah sudah layak digunakan. Instrumen validasi terhadap $e$-modul yang dikembangkan ada dua jenis yaitu instrumen untuk ahli materi dan instrumen untuk ahli media.

Adapun kisi-kisi instrumen angket validasi ahli materi yang digunakan dalam pengembangan $e$ modul ini seperti pada tabel 1 berikut:

Tabel 1. Kisi-Kisi Instrumen Validasi Ahli Materi

\begin{tabular}{clc}
\hline No. & \multicolumn{1}{c}{ Indikator } & No. Butir Soal \\
\hline 1. & $\begin{array}{l}\text { Kesesuaian uraian materi dengan standar kompetensi (SK) } \\
\text { dan kompetensi dasar (KD) }\end{array}$ & 1 \\
2. & Kedalaman materi & $2-3$ \\
3. & Kejelasan penyajian materi & 4 \\
4. & Penjabaran materi & 5 \\
5. & Keakuratan materi & $6-9$ \\
6. & Keterkaitan materi dengan soal & $10-11$ \\
7. & Ketepatan pemilihan gambar, animasi, dan video & $12-13$ \\
8. & Ketepatan penggunaan bahasa & $14-15$ \\
9. & Tipografi & 16 \\
\hline & & (Ringo, 2017)
\end{tabular}

Adapun kisi-kisi instrumen angket validasi ahli media yang digunakan dalam pengembangan $e$ modul seperti pada tabel 2 berikut:

Tabel 2. Kisi-Kisi Instrumen Validasi Ahli Media

\begin{tabular}{clc}
\hline No. & \multicolumn{1}{c}{ Indikator } & No. Butir Soal \\
\hline 1. & Ketepatan dan kesesuaian desain & $1-2$ \\
2. & Penggunaan audio & 3 \\
3. & Tampilan layout/visual & $4-10$ \\
4. & Desain tata letak isi & $11-15$ \\
5. & Usabilitas & 16 \\
6. & Interaktif & $17-18$ \\
7. & Self Instructional & 19 \\
8. & Self Contained & 20 \\
9. & Stand Alone & 21 \\
10. & Adaptive & 22 \\
11. & User Friendly & 23 \\
\hline
\end{tabular}

Setelah tim ahli melakukan validasi terhadap $e$-modul yang dikembangkan, maka dilakukan revisi sesuai saran dan komentar tim ahli. Selanjut tim ahli memvalidasi kembali hingga diperoleh kesimpulan bahwa $e$-modul tidak perlu direvisi lagi dan tim ahli telah memberikan izin untuk dilanjutkan pada tahap berikutnya yaitu tahap uji coba produk untuk pengambilan data persepsi siswa.

$E$-modul yang telah selesai divalidasi oleh tim ahli dan sudah layak diuji cobakan, maka selanjutnya $e$-modul diuji cobakan kepada siswa sebagai subjek uji coba. Adapun kisi-kisi instrumen angket persepsi siswa terdapat pada tabel 3 berikut: 
Tabel 3. Kisi-Kisi Angket Persepsi Siswa

\begin{tabular}{lll}
\hline Aspek & \multicolumn{1}{c}{ Indikator } & No. Butir Soal \\
\hline Tampilan & Kejelasan teks & 1 \\
& Kejelasan gambar, animasi, dan video & $2,3,4$ \\
& Kemenarikan gambar, animasi, dan video & 5 \\
Penyajian & Penyajian materi & 6,7 \\
Materi & Kejelasan dan kesederhanaan Kalimat & 8,9 \\
& Kesesuaian contoh dengan Materi & 10 \\
& Kesesuaian gambar, animasi, dan video. & 11 \\
Manfaat & Kemudahan belajar & 12,13 \\
& Ketertarikan menggunakan modul & 14 \\
& Peningkatan motivasi belajar & 15 \\
\hline
\end{tabular}

Teknis Analisis Data

1) Hasil Validasi Ahli

Tim ahli memberikan penilaian seperti pertimbangan, pendapat, komentar dan masukan pada kolom di bagian kolom komentar yang telah disediakan di dalam angket sehingga dihasilkan data kualitatif. Tim ahli juga memberikan penilaian berupa skor penilaian terhadap $e$-modul (menggunakan skala likert) sehingga diperoleh data kuantitatif. Pada angket tim ahli digunakan pilihan jawaban bagi tim ahli menggunakan skala Likert untuk mengukur pendapat tim ahli terhadap modul yang dikembangkan (Ridwan, 2013). Skala Likert yang digunakan berupa: Sangat Tidak Baik (1), Tidak Baik (2), Cukup Baik (3), Baik (4) dan Sangat Baik (5).

Data hasil validasi kemudian dianalisis dengan menghitung persentase pada setiap butir pertanyaan yang terdapat di angket dan dilanjutkan dengan mengkriteriakannya (Arikunto, 2013). Adapun rumus yang digunakan peneliti untuk mempersentasekan setiap butir pertanyaan tersebut adalah sebagai berikut:

Keterangan:

$$
\mathrm{A} \%=\mathrm{B} / \mathrm{C} \times 100 \%
$$

$\mathrm{A}=$ Persentase kelayakan $(\%)$

$\mathrm{B}=$ Skor yang diperoleh

$\mathrm{C}=$ Skor yang diharapkan

Dengan menggunakan persamaan (3.1) di atas, maka dapat diperoleh bahwa nilai persentase kelayakan terkecil dan terbesar pada angket yang digunakan adalah sebesar $20 \%$ dan $100 \%$.

Untuk menentukan jarak interval antara jenjang sikap mulai dari sangat tidak baik hingga sangat baik digunakan rumus berikut:

Keterangan:

$$
\mathrm{i}=(\mathrm{y}-\mathrm{x}) / \mathrm{N}
$$

$\mathrm{i}=$ jarak interval

$\mathrm{y}=$ skor tertinggi

$\mathrm{x}=$ skor terendah

$\mathrm{N}=$ jumlah kelas interval

Dengan memasukkan nilai yang diperoleh dari persamaan (1) ke persamaan (2) dan jumlah kelas interval yang digunakan sebanyak 5 kelas, maka pada penelitian ini range persentase dan kriteria kualitatif yang digunakan adalah sebagai berikut:

Tabel 4. Range Persentase dan Kriteria Kualitatif

\begin{tabular}{lll}
\hline No. & Interval Persentase & \multicolumn{1}{c}{ Kriteria } \\
\hline 1. & $84 \% \leq$ skor $\leq 100 \%$ & Sangat Baik \\
2. & $68 \% \leq$ skor $\leq 84 \%$ & Baik \\
3. & $52 \% \leq$ skor $\leq 68 \%$ & Cukup Baik \\
4. & $36 \% \leq$ skor $\leq 52 \%$ & Tidak Baik \\
5. & $20 \% \leq$ skor $\leq 36 \%$ & Sangat Tidak Baik \\
\hline
\end{tabular}




\section{2) Persepsi Siswa}

Angket persepsi siswa yang digunakan dilakukan analisis validitas dan realibilitasnya.

a. Analisis Validitas

Validitas adalah suatu ukuran yang menunjukkan tingkat-tingkat kesahihan suatu instrumen. (Arikunto, 2013) menyebutkan bahwa secara umum ada dua macam validitas, yaitu validitas logi dan validitas empiris. Validitas logis diperoleh dengan suatu usaha hati-hati melalui cara-cara yang benar mengikuti teori dan ketentuan yang ada sehingga menurut penalaran akan dicapai suatu tingkat validitas yang dikehendaki. Sementara itu sebuah instrumen dikatakan memiliki validitas empiris apabila sudah diuji dari pengalaman.

Adapun pada penelitian pengembangan ini digunakan validitas logis dalam menganalisis angket persepsi siswa. Validitas logis yang dapat dicapai oleh sebuah instrumen terbagi menjadi dua macam, yaitu validitas isi dan validitas konstrak. Validitas isi bagi sebuah instrumen menunjuk suatu kondisi bahwa sebuah instrumen disusun berdasarkan isi materi pelajaran yang dievaluasi untuk instrumen tes dan ditinjau dari segi indikator yang ditanyakan untuk instrumen berupa angket. Selanjutnya validitas konstrak sebuah instrumen menunjuk kepada suatu kondisi suatu intrumen yang disusun berdasarkan konstrak aspek-aspek yang harus dievaluasi .

b. Analisis Realibilitas

Reliabilitas tes berhubungan dengan konsistensi hasil pengukuran, yaitu seberapa konsistensi skor tes dari satu pengukuran ke pengukuran lainnya (Hamzah \& Koni, 2013). Menurut (Arikunto, 2013) realibilitas menunjuk pada satu pengertian bahwa suatu instrumen cukup dapat dipercaya untuk digunakan sebagai alat pengumpulan data karena instrumen tersebut sudah baik. Instrumen yang baik tidak akan bersifat tendensus mengarahkan responden untuk memilih jawaban-jawaban tertentu. Reliabilitas tes berhubungan dengan konsistensi hasil pengukuran, yaitu seberapa konsisten skor tes dari satu pengukuran ke pengukuran berikutnya. Reliabilitas dinyatakan dengan koefisien reliabilitas yaitu koefisien korelasi yang menunjukkan derajat hubungan antara dua hasil pengukuran yang diperoleh dari instrumen atau prosedur yang sama. Koefisien reliabilitas pada suatu instrumen dapat dihitung dengan menggunakan rumus koefisien Alpha. Sebelum perhitungan terlebih dahulu dibuat tabel kerja dengan langkah-langkah sebagai berikut.

1) Item-item yang dinyatakan tidak valid dikeluarkan dari instrumen. Jadi reliabilitas instrumen hanya dihitung untuk item-item yang dinyatakan valid.

2) $X$ dan $X^{2}$ dihitung untuk tiap-tiap item dan skor total, dengan memakai rumus (Riduwan, 2013) :

$$
S_{i}=\frac{\Sigma X_{i}^{2}-\frac{\left(\Sigma X_{i}\right)^{2}}{N}}{N}
$$

Keterangan:

$S_{i} \quad=$ variansi skor tiap-tiap item

$N \quad=$ jumlah responden

$X_{i}^{2} \quad=$ Jumlah kuadrat item ke $\mathrm{X}-\mathrm{i}$

$\left(\sum X_{i}\right)^{2}=$ Jumlah item Xi dikuadratkan

Untuk menghitung varian total adalah sebagai berikut:

$$
S_{t}=\frac{\Sigma X t^{2}-\frac{\left(\Sigma X_{t}\right)^{2}}{N}}{N}
$$

Keterangan:

$S_{i} \quad=$ variansi skor tiap-tiap item

$N \quad=$ jumlah responden

$X_{i}^{2} \quad=$ Jumlah kuadrat $\mathrm{X}$ total

$\left(\sum X_{i}\right)^{2}=$ Jumlah $X$ total dikuadratkan

Pengembangan E-Modul Fisika.... (Irna Tri Putri, dkk) hal:52-62 
Selanjutnya adalah harga koefisien reliabilitas instrumen dihitung dengan menggunakan rumus Alpha sebagai berikut (Riduwan, 2013):

$$
r_{11}=\left(\frac{k}{k-1}\right)\left(1-\frac{\Sigma s_{i}}{s_{t}}\right)
$$

Keterangan:

$k \quad=$ banyaknya butir pertanyaan atau banyaknya butir soal.

$s_{i} \quad=$ variansi butir

$\sigma_{t}^{2} \quad=$ variansi total

Koefisien reliabilitas ter berkisar antara $0,00-1,00$ dengan perincian korelasi diperlihatkan pada Tabel 5 berikut:

Tabel 5. Interpretasi nilai $\mathrm{r}$

\begin{tabular}{lll}
\hline No. & Besarnya nilai $\mathrm{r}$ & Interpretasi \\
\hline 1. & $0,800-1,00$ & Sangat tinggi \\
2. & $0,600-0,800$ & Tinggi \\
3. & $0,400-0,600$ & Cukup \\
4. & $0,200-0,400$ & Rendah \\
5. & $0,000-0,200$ & Sangat rendah \\
\hline
\end{tabular}

c. Analisis Skala Angket

Data yang diperoleh dari penyebaran angket persepsi siswa terhadap e-modul berupa skor pada setiap pernyataan yang terdapat di dalam angket. Data berupa skor ini akan dirubah menjadi pernyataan akhir yang merupakan data kuantitatif. Berikut adalah langkah-langkah menganalisis data angket persepsi siswa.

a) Hasil checking dikuantitatifkan pada angket menjadi skor sesuai bobot yang telah ditentukan dan membuat tabulasi.

b) Persentase pada butir pertanyaan dihitung.

c) Persentase untuk masing-masing pernyataan dihitung menggunakan rumus sebagai berikut:

$$
R S=\frac{n}{N} \times 100 \%
$$

Keterangan:

$R S=$ persentase pertanyaan

$n \quad=$ jumlah nilai pada pertanyaan yang diperoleh

$N$ = jumlah nilai maksimum pada pernyataan

d) Langkah selanjutnya adalah kriteria atau kategori ditentukan pada masing-masing butir pernyataan. Dengan menggunakan persamaan (3.1) dan (3.2) serta hanya menggunakan empat kelas interval, maka range persentase dan kriteria kuantitatif yang digunakan adalah sebagai berikut:

Tabel 6. Rumusan Kriteria

\begin{tabular}{lll}
\hline No. & Rentang Skor & Kriteria \\
\hline 1. & $81,25 \leq$ skor $\leq 100$ & Sangat Baik \\
2. & $62,5 \leq$ skor $\leq 81,25$ & Baik \\
3. & $43,75 \leq$ skor $\leq 62,5$ & Tidak Baik \\
4. & $25 \leq$ skor $\leq 43,75$ & Sangat Tidak Baik \\
\hline
\end{tabular}




\section{Hasil dan Pembahasan}

Penelitian pengembangan ini menggunakan model pengembangan ADDIE. Adapun tahapannya dimulai dari Analysis (menganalisis), Design (merancang), Development (mengembangkan), Implementation (mengimplementasikan). Adapun dalam penelitian pengembangan ini, tahap Implementation (mengimplementasikan) tidak dilakukan, tahap model pengembangan ADDIE yang dilakukan peneliti hanya sampai pada tahap development (mengembangkan). Hal ini dikarenakan tujuan penelitian hanya untuk mengetahui hasil pengembangan dan persepsi siswa, sehingga tahap Implementation (mengimplementasikan) tidak perlu dilakukan karena tujuan penelitian telah tercapai. Adapun tahap Evaluasi adalah dilakukan setiap saat guna kebutuhan revisi. Penelitian pengembangan ini menghasilkan $e$-modul fisika berbasis pendekatan saintifik menggunakan $3 D$ Pageflip Professional pada materi Teori Kinetik Gas untuk SMA kelas XI sebagai produk akhir dan memperoleh persepsi siswa terhadap produk.

\section{Hasil Tahapan-tahapan Pengembangan}

1) Hasil Tahap Analysis (menganalisis)

Analysis (menganalisis) merupakan tahap awal dalam memulai penelitian pengembangan ini. Pada tahap ini, dilakukan studi pendahuluan berupa penyebaran angket kepada siswa dan guru fisika di sekolah. Hal ini dilakukan untuk mengetahui permasalahan yang dihadapi siswa dalam proses pembelajaran fisika. Angket tersebut berupa angket studi pendahuluan dan angket kebutuhan yang disebarkan kepada siswa kelas XII MIPA 5 SMA Negeri 1 Muaro Jambi dan angket wawancara terhadap guru fisika SMA Negeri 1 Muaro Jambi.

2) Hasil Tahap Design (merancang)

Tahap selanjutnya yaitu tahap Design (merancang). Tahap desain ini bertujuan untuk merancang produk yang akan dikembangkan. Beberapa perangkat dan bahan yang peneliti siapkan sebelum merancang $e$-modul adalah Silabus mata pelajaran fisika SMA kelas XI kurikulum 2013 revisi 2016, materi Teori Kinetik Gas, dan beberapa media pendukung seperti gambar, video, dan simulasi.

3) Hasil Tahap Development (Pengembangan)

Tahap Pengembangan adalah tahap terakhir dalam penelitian pengembangan ini. Proses yang dilakukan pada tahap pengembangan adalah pembuatan, validasi, serta uji coba pengembangan untuk mengetahui kelayakan $e$-modul yang telah dikembangkan, dimana pengembangan $e$-modul disesuaikan dengan kebutuhan siswa yang diketahui dari hasil tahap analisis. Pembuatan $e$-modul sesuai pada tahap desain, penulisan materi dilakukan di microsoft powerpoint yang dapat diubah formatnya menjadi $p d f$ guna di import ke software $3 D$ Pageflip Professional. Untuk validasi terdapat dua jenis, yaitu validasi materi dan validasi media yang dilanjutkan dengan revisi sesuai masukan validator-validator tersebut.

\section{a. Validasi materi}

Proses validasi materi dilakukan sebanyak dua kali hingga akhirnya $e$-modul yang dikembangkan dari segi materi sudah layak untuk diuji cobakan. Proses validasi materi ini menggunakan angket yang berisikan 16 pertanyaan dari 9 indikator seperti yang tertera pada Tabel 1 .

Adapun hasil validasi materi tahap I diperoleh persentase rata-rata sebesar 72,5\%. Dari hasil ini, produk yang dikembangkan dinyatakan baik dari aspek materi. Dengan kesimpulan validator materi yang menyatakan bahwa $e$-modul cukup baik dengan banyak revisi. Sedangkan Adapun hasil validasi materi tahap II diperoleh persentase rata-rata sebesar $80 \%$. Dari hasil ini, produk yang dikembangkan dinyatakan baik dari aspek materi. Dengan hasil ini, diperoleh peningkatan persentase rata-rata dari hasil validasi materi tahap I ke validasi materi tahap II sebesar 7,5\%. Kesimpulan validator materi bahwa $e$-modul ini sudah baik dan layak digunakan untuk uji coba tanpa adanya tambahan revisi.

\section{b. Validasi media}

Proses validasi media ini berlangsung juga sebanyak dua kali hingga validator media memberikan keterangan bahwa $e$-modul yang dikembangkan telah layak untuk diuji cobakan. Adapun hasil validasi aspek media tahap I secara keseluruhan didapatkan persentase rata-rata sebesar $80,8 \%$. 
Dari hasil validasi ini, validator menyimpulkan bahwa $e$-modul ini baik dan dapat digunakan dengan sedikit revisi. Sedangkan hasil validasi aspek media tahap II secara keseluruhan didapatkan persentase rata-rata sebesar $81,7 \%$ dengan kategori baik. Dari hasil ini, terlihat bahwa terdapat peningkatan persentase rata-rata dari validasi media tahap I ke validasi media tahap II sebesar 0,9\%. Peningkatannya tidak terlalu segnifikan karena validator hanya menyarankan sedikit revisi, karena menurut validator $e$-modul yang dikembangkan saat validasi tahap I sudah bisa dikatakan baik. Pada tahap II validasi ini, validator menyimpulkan bahwa $e$-modul yang dikembangkan sudah baik dan dapat digunakan tanpa revisi serta sudah layak diuji cobakan kepada siswa.

c. Revisi Produk

a) Revisi validasi ahli materi

$\checkmark$ Perbaiki Indikator Pembelajaran, Tujuan Pembelajaran dan Kata Kunci.

$\checkmark$ Perbaiki kalimat penjelas pada setiap materi.

$\checkmark$ Perbaiki materi yang masih terlalu matematis.

$\checkmark$ Perbaiki konsep materi dengan baik.

$\checkmark$ Perjelas asal-usul teori.

$\checkmark$ Perbaiki contoh soal dan soal latihan agar lebih bervariasi.

b) Revisi validasi ahli media

$\checkmark$ Perbaiki paragraf yang terlalu panjang agar tidak bersifat informatif.

$\checkmark$ Perbaiki simbol-simbol pendekatan saintifik agar lebih menarik.

Data Hasil Uji Coba Produk

1) Validitas dan Reliabilitas Angket Persepsi Siswa

Sebelum digunakan untuk mengambil data, angket harus melalui proses validasi dan uji reliabilitas. Adapun angket persepsi siswa yang merupakan instrumen non tes, sehingga cukup melakukan validitas logis berupa validitas konstruk. Angket ini disusun berdasarkan kisi-kisi serta aspek-aspek yang akan diukur. Selanjutnya Angket yang digunakan oleh peneliti dilakukan konsultasi pada ahli yaitu pada dosen pembimbing. Disamping itu, angket yang digunakan oleh peneliti adalah angket yang juga pernah digunakan oleh beberapa penelitian yang relevan. Berdasarkan penelitianpenelitian yang menggunakan angket tersebut, hasilnya menunjukkan bahwa angket tersebut memiliki reliabilitas sangat tinggi sehingga bisa dipercaya dan bisa digunakan untuk mengambil data yang diinginkan. Oleh karena itu, peneliti mengadopsi angket ini sebagai angket sebagai angket persepsi siswa terhadap $e$-modul yang dikembangkan.

Setelah angket dinyatakan valid, yaitu sudah digunakan oleh beberapa penelitian relevan dan dikonsultasikan kepada dosen pembimbing, peneliti tetap menguji reliabilitas kembali. Uji reliabilitas dilakukan dengan cara perhitungan koefisien korelasi dari persamaan Alpha. Dari perhitungan tersebut didapatkan bahwa koefisien korelasinya adalah $r 11=1,0680681$, atau dapat dibulatkan menjadi $r 11$ $=1,00$. Hasil ini menunjukkan bahwa angket yang digunakan memiliki reliabilitas yang sangat tinggi sehingga bisa dipercaya dan bisa digunakan untuk mengambil data yang diinginkan, yaitu data persepsi siswa terhadap $e$-modul yang dikembangkan.

\section{2) Data Persepsi Siswa}

Setelah melalui proses validasi, $e$-modul dikategorikan baik dari aspek materi dan baik untuk aspek media. Adapun tahapan selanjutnya adalah melakukan uji coba untuk mengambil data persepsi siswa. Pengumpulan data persepsi siswa adalah langkah terakhir pada penelitian pengembangan ini. Proses pengumpulan data persepsi siswa menggunakan angket yang dikembangkan untuk melihat persepsi siswa pada 3 aspek, antara lain yaitu: tampilan, penyajian materi, dan manfaat. Berdasarkan angket yang telah diisi oleh siswa maka diperoleh hasil analisis persentase sebagai berikut: 
Tabel 7. Hasil Persepsi Siswa

\begin{tabular}{lll}
\hline \multicolumn{1}{c}{ Aspek } & \multicolumn{1}{c}{$\begin{array}{c}\text { Persentase Rata-rata } \\
\text { Indikator }(\%)\end{array}$} & Kategori \\
\hline Tampilan & 82,4 & Baik \\
Penyajian Materi & 80,8 & Baik \\
Manfaat & 82,25 & Sangat Baik \\
\hline
\end{tabular}

Dari analisis tersebut, diperoleh nilai skor rata-rata antara lain yaitu 82,4 (Sangat Baik), 80,8 (Baik), dan 82,25 (Sangat Baik). Sehingga dapat dilihat dari hasil tersebut, menunjukkan bahwa $e$ modul fisika berbasis pendekatan saintifik menggunakan 3D Pageflipp Professional pada materi Teori Kinetik Gas yang dikembangkan telah memiliki kategori yang layak untuk dipergunakan dalam proses pembelajaran.

\section{Simpulan}

E-modul Fisika berbasis Pendekatan Saintifik menggunakan 3D Pageflipp Professional pada materi Teori Kinetik Gas untuk SMA kelas XI telah direvisi dari tim ahli, baik tim ahli materi maupun tim ahli media. Revisi tersebut bertujuan untuk memperbaiki $e$-modul elektronik sesuai dengan penilaian dan komentar yang diperoleh dari validator, sehingga $e$-modul dihasilkan yang layak untuk diuji cobakan. Validasi Materi berlangsung dua tahap, adapun hasilnya adalah sebagai berikut: tahap pertama diperoleh persentase rata rata sebesar $72,8 \%$ dengan kriteria baik, tahap kedua diperoleh persentase rata-rata sebesar $80 \%$ dengan kriteria baik. Validasi ahli media juga berlangsung sebanyak dua tahap yang dilakukan untuk memperoleh kelayakan e-modul dari aspek media. Adapun hasilnya adalah sebagaiberikut: Validasi tahap pertama diperoleh persentase rata rata sebesar 80,8\% dengan kriteria baik, Validasi tahap kedua diperoleh persentase rata-rata sebesar 81,7 \% dengan kriteria baik. Dari hasil validasi ahli materi dan ahli media, maka tim ahli menyatakan bahwa $e$-modul ini telah layak untuk diuji cobakan. Dengan dilakukannya uji coba $e$-modul terhadap siswa kelas XII MIPA SMA Negeri 1 Muaro Jambi, maka didapatkan hasil sebagai berikut: kkor rata-rata dari aspek tampilan $e$-modul sebesar 82,4 (Sangat Baik). Skor rata-rata dari aspek penyajian materi dalam $e$ modul sebesar 80,8 (Baik). Skor rata-rata dari aspek kebermanfaatan $e$-modul sebesar 82,25 (Sangat Baik). Hasil analisis terhadap data persepsi siswa ini menunjukkan bahwa $e$-modul Fisika berbasis Pendekatan Saintifik menggunakan 3D Pageflipp Professional pada materi Teori Kinetik Gas untuk SMA kelas XI adalah baik dan layak untuk digunakan sebagai bahan ajar mandiri bagi siswa SMA kelas XI.

\section{Referensi}

Anggraini, R., Hendri, M., \& Basuki, R. F. (2017). Pengembangan E-modul Fisika Berbasis Pendekatan Saintifik Pada Materi Gerak Melingkar Untuk SMA/MA Kelas X. Revository Universitas Jambi, 1-11.

Arikunto, S. (2013). Prosedur Penelitian:Suatu Pendekatan Taktik. In bumi aksara.

Branch, R. M. (2010). Instructional design: The ADDIE approach. In Instructional Design: The ADDIE Approach. https://doi.org/10.1007/978-0-387-09506-6

Depdiknas. (2008). Penulisan Modul. Penulisan Modul.

Ghaliyah, S., Bakri, F., \& Siswoyo. (2015). Pengembangan Modul Elektronik Berbasis Model Laerning Cycle 7E pada Pokok Bahasan Fluida Dinamik untuk Siswa SMA Kelas XI. Prosiding Seminar Nasional Fisika (E-Journal) SNF2015.

Harjanta, A. T. J., \& Herlambang, B. A. (2018). Rancang Bangun Game Edukasi Pemilihan Gubernur 
Jateng Berbasis Android Dengan Model ADDIE. Jurnal Transformatika, 16(1). https://doi.org/10.26623/transformatika.v16i1.894

Kemendikbud. (2014). Materi Pelatihan Guru Implementasi Kurikulum 2013. Badan Pengembangan Sumber Daya Manusia Pendidikan Dan Kebudayaan Dan Penjaminan Mutu Pendidikan Kementerian Pendidikan Dan Kebudayaan.

Priatna, I. K., Putrama, I. M., \& Divayana, D. G. H. (2017). Pengembangan E-Modul Berbasis Model Pembelajaran Project Based Learning Pada Mata Pelajaran Videografi untuk Siswa Kelas X Desain Komunikasi Visual di SMK Negeri 1 Sukasada. Jurnal Nasional Pendidikan Teknik Informatika (JANAPATI). https://doi.org/10.23887/janapati.v6i1.9931

Riduwan. (2013). Belajar Mudah Penelitian Untuk Guru Karyawan dan Peneliti Pemula. In Belajar Mudah Penelitian Untuk Guru Karyawan dan Peneliti Pemula.

Sugiyono. (2018). Metode Peneiltian Kuantitatif, Kualitatif dan R\&D. In Alfabeta Bandung.

Yoto, Y., \& Wiyono, K. (2016). Pengembangan Multimedia Interaktif Pembelajaran Teori Kinetik Gas Berbantuan Lectora Inspire Untuk Siswa Sekolah Menengah Atas (Sma). Jurnal Inovasi Dan Pembelajaran Fisika, 2(2), 211-219. 